\title{
Plans for research watchdog praised, but it may lack teeth
}

\section{Jim Giles, London}

British biomedical science is to get its first watchdog. But even as details of the plan are being finalized, its architects have generated controversy by saying that they would consider accepting funding from the pharmaceutical industry.

Critics also fear that the proposed UK Panel for Health and Biomedical Research Integrity — which will operate under the umbrella of Universities UK (UUK) - may lack the teeth to police research properly.

Plans to establish the panel should be completed next month at a board meeting of the UUK, which represents most of Britain's higher-education institutes.

The idea of the panel has been spearheaded by Michael Farthing, principal of St George's Hospital Medical School in London. It has the approval of the government, and the Department of Health is currently helping to select the first panel members. The body will initially cover all biomedical research in universities and the National Health Service.

The need for an independent body to oversee investigations of misconduct, such as plagiarism and fraud, has been made clear by several science organizations in recent years.

But although the panel is likely to act as a safe haven for whistle-blowers, it will not itself investigate misconduct allegations. John Pritchard, a senior policy adviser at Sheffield Hallam University who is working on the plans on behalf of UUK, says the panel will instead advise institutions on how to run inquiries and nominate participants.

"I'd like to see a rigorous system of investigation and enforcement," says Brian Gennery, president of the Faculty of Pharmaceutical Medicine at the Royal Colleges of Physicians, one of the first UK organizations to promote the need for a research-integrity watchdog. "Then I would have much more confidence in this new body."

Some organizations established elsewhere to oversee research integrity, such those in Denmark and the United States, have the power to run their own inquiries. Pritchard declined to comment on this issue until details of the plan have been approved by UUK, saying only that the whistle-blower facility alone would have a positive effect on subsequent investigations by employers.

The panel will also develop a nonmandatory code of conduct for biomedical researchers and raise awareness of misconduct through local events.

If UUK approval is secured next month, Pritchard expects panel members to be nominated in May and to start work by October.
The panel would initially be established for a three-year period, pending a review of its performance.

Pritchard discussed the plans on 11 March at a London meeting of the Committee on Publication Ethics, an association of journal editors. When Pritchard mentioned that UUK was considering accepting funding from a range of sources - including the pharmaceutical industry - some delegates responded angrily.

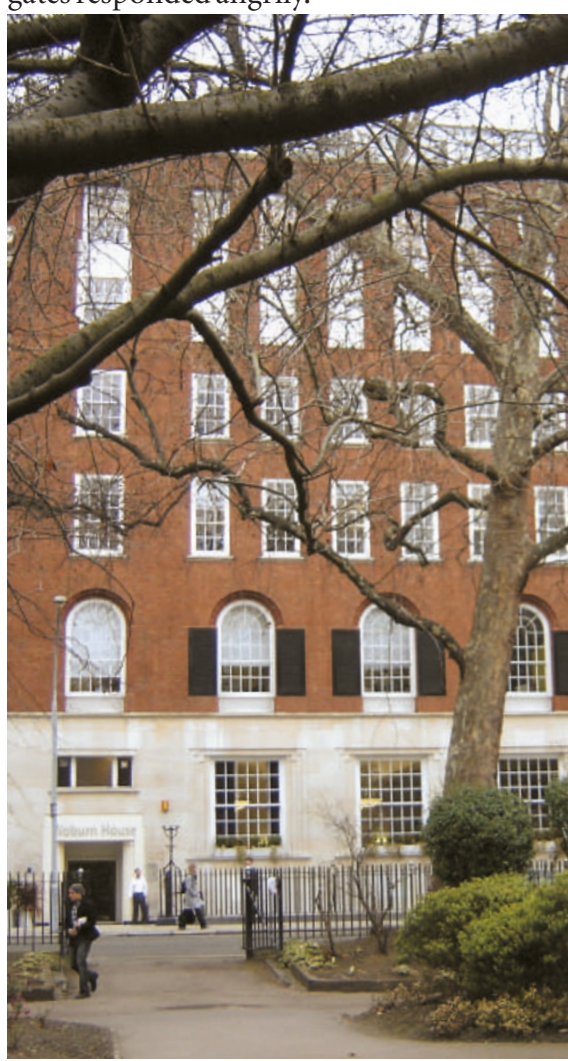

Bright idea: Universities UK will discuss who funds a new body to oversee biomedical research.

"How will pharmaceutical sponsorship square with public confidence in this body?" asks Iona Heath, a London-based general practitioner and chairwoman of the British Medical Journal's ethics committee. She points out that the behaviour of the industry is currently under investigation by parliament following claims that some firms failed to publish sensitive research (see Nature 429, 793; 2004). "This is not the right time to jump into bed with them," says Heath.

Pritchard says no decision on funding has been taken, but adds that the pharmaceutical industry is a major funder of biomedical research and it would be a mistake not to engage with them. "They're a stakeholder," he says. "It will be a missed opportunity if their responsibility is put aside."

\section{Row flares over attempt to dilute radioactive waste}

Emma Marris, Washington

Independent experts have finally been given the chance to comment on highly contentious plans for disposing of almost 100 million gallons of radioactive waste.

The waste was generated during the cold war when spent fuel rods from nuclear reactors were converted to weapons-grade plutonium. It is now being kept in massive tanks at Department of Energy sites in Idaho, South Carolina and Washington state.

The problem of its disposal has been a bone of bitter political contention for decades. Particularly rancorous is the issue of whether the energy department should have the power to reclassify certain waste so that it can deal with it more flexibly and cheaply. This power was successfully challenged by an environmental group, the Natural Resources Defense Council, in 2003.

The department regained that power this year in Idaho and South Carolina, when Congress's Armed Services Committee inserted a provision into the National Defense Authorization Act to make it legal. But under pressure, the committee conceded that 21 independent experts at the National Academy of Sciences should be allowed to assess the technical risks in the agency's proposed disposal plan.

The plan calls for various treatments for the contents of the storage tanks. Liquids that are less radioactive would be dealt with on-site. The radioactive salt cake would be extracted, processed and shipped to a long-term repository. Concrete would then be added to the highly radioactive sludge that has settled at the bottom of the tanks to dilute the radioactivity.

It is this last step, which critics call 'disposal by dilution', that the experts, who met on 7 March, are looking at. They will assess the long-term safety of the technique and will examine alternatives.

Environmentalists are angry that the energy department has regained freedom from rigorous oversight in nuclear-waste disposal. They hope that the panel will expose what they see as an inadequate clean-up and a lack of credibility.

Energy department spokesman Joe Davis denies the lack of credibility. "Many agree that this is the way to proceed," he says, adding that the agency reviews reports from the National Academies and "takes their opinions and thoughts into account as we go about our work". 